\title{
ANALISIS PEMASARAN KELAPA DAN PRODUK TURUNANNYA DI DESA PELANDUK KECAMATAN MANDAH KABUPATEN INDRAGIRI HILR
}

\author{
Nina Sawitri, Hemeria, Siti Zubaidah \\ Program Studi Agribisnis Fakultas Pertanian UNISI \\ Email: ninasawitri@gmail.com
}

\begin{abstract}
ABSTRAK
Kecamatan Mandah merupakan daerah penghasil kelapa di Kabupaten Indragiri Hiir, salah satunya berada di Desa Pelanduk. Tujuan penelitian ini adalah menganalisi pemasaran kelapa dan produk turunannya yaitu gula kelapa yang ada di Desa Pelanduk Kecamatan Mandah. Metode penelitian yang digunakan adalah analisis marjin pemasaran, farmer's share dan efesiensi pemasaran. Hasil penelitian menunjukkan bahwa margin pemasaran kelapa pada saluran 1 adalah Rp.1.740,00 atau 58,00\%, sedangkan margin pada saluran II adalah Rp.1,140 atau $38,00 \%$. Farmer's share kelapa pada saluran I yaitu Rp.10,77 atau 3,59\% sedangkan pada farmer's share pada saluran II yaitu Rp.70,21 atau 234,03\% Efesiensi pemasaran kelapa pada saluran I yaitu 3,90\%, sedangkan efesiensi pada saluran II yaitu $8,26 \%$. Besarnya marjin pemasaran gula kelapa pada saluran II adalah Rp 4.750,00 dan pada saluran III sebesar Rp 5.425,00 per kilogram. Pada saluran I tidak terdapat marjin pemasaran karena petani menjual sendiri gula kelapanya kepada konsumen. Nilai efisiensi gula kelapa pada saluran I adalah $0,67 \%$, dan saluran II sebesar $1,21 \%$ sedangkan pada saluran III yaitu sebesar $6,15 \%$.
\end{abstract}

Kata Kunci: Kelapa. Gula Kelapa, Saluran Pemasaran, Marjin Pemasarn, Farmer's share, Efesiensi Pemasaran

\begin{abstract}
Mandah District is a coconut-producing area in Indragiri Hiir Regency, one of which is located in Pelanduk Village. The purpose of this study was to analyze the marketing of coconuts and their derivative products, coconut sugar in Pelanduk Village, Mandah District. The research method used is the analysis of marketing margins, farmer's share and marketing efficiency. The results showed that the marketing margin for channel 1 was Rp.1,740.00 or $58.00 \%$, while the margin for channel II was Rp.1,140 or $38.00 \%$. Coconut farmer's share in channel I is Rp. 10.77 or $3.59 \%$ while in farmer's share in channel II is Rp.70.21 or $234.03 \%$ Coconut marketing efficiency in channel I is $3.90 \%$, while efficiency in channel II that is $8.26 \%$. The amount of marketing margin for coconut sugar in
\end{abstract}


channel II is Rp 4,750.00 and in channel III it is Rp 5,425.00 per kilogram. In channel I there is no marketing margin because farmers sell their own sugar to consumers. The efficiency value of coconut sugar in channel I was $0.67 \%$, and channel II was $1.21 \%$ while in channel III it was $6.15 \%$.

Keywords: Coconut, Coconut Sugar, Marketing Channels, Market Margin, Farmer's Share, Marketing Efficiency

\section{PENDAHULUAN}

Pertanian di Indonesia adalah pertanian tropika, karena sebagian besar daerahnya berada di daerah katulistiwa. Kelapa merupakan salah satu komoditi yang dapat tumbuh di daerah tropis dan merupakan sektor pertanian yang sangat menunjang bagi sektor industri, karena hampir seluruh bagian tanaman ini bermanfaat bagi kehidupan manusia (Luntungan,2005). Salah satu daerah penghasil kelapa di Kabupaten Indragiri Hilir adalah Desa Pelanduk Kecamatan Mandah. Tanaman kelapa ini sudah lama dibudidayakan oleh masyarakat di Desa Pelanduk sebagai sumber pendapatan. Salah satu upaya untuk meningkatkan produktivitas yang berdampak kepada peningkatan petani adalah dengan mengelola input usahatani yang berdampak kepada peningkatan pendapatan petani adalah dengan mengelola input usaha tani seperti tenaga kerja, pendapatan, pendidikan, luas lahan dan keikutikutan serta dalam kelompok tani secara optimal dan efektif (Luntungan,2005).

Cara pemasaran yang dilakukan petani kelapa dan gula kelapa di Desa Pelanduk, Kecamatan Mandah, Kabupaten Indragiri Hilir. dilakukan dengan dua cara, yaitu secara langsung yaitu petani menjual produknya langsung ke konsumen. Dan secara tidak langsung yaitu petani menjual produknya melalui penyalur yaitu melalui pedagang pengumpul dan pedagang pengencer.

dapat Pemasaran yang dianggap baik, jika tercipta keadaan yang dapat memperoleh kepuasan bagi semua pihak, yaitu produsen, lembaga-lembaga pemasaran dan konsumen. Kepuasan yang dimaksud antara lain adalah kepuasan antara harga yang diterima produsen, imbalan dan jasa yang diterima lembaga pemasaran serta kepuasan terhadap barang-barang dan jasa-jasa yang diterima konsumen. Antara produsen dan konsumen terdapat perantara yang terlibat dalam arus pengaliran barang. Jasa perantara menyebabkan konsumen dapat membeli barang dengan mudah sesuai keinginannya.

Kendala-kendala

yang dihadapi dalam memproduksi gula kelapa cukup banyak, salah satu yang dihadapi terutama dalam proses produksi gula kelapa (industri rumah 
tangga) ketersediaan tenaga penyadap merupakan masalah, hal ini berkaitan dengan kondisi pekerjaan penyadap yaitu; Umumnya pohonnya yang diusahakan rata-rata berumur tua dan pohonnya cukup tinggi (b) Tidak seluruh tanaga yang ada mau dan mampu melakukan kegiatan penyadapan, karena adanya resiko yang cukup besar dan (c) Pada desa yang terbuka, terdapat alternatif pekerjaan yang lebih menarik di samping tenaga kerja penyadap juga masalah ketersediaan bahan baku terutama pada musim penghujan dimana kayu bakar tidak cukup tersedia masalah yang lain adalah lemahnya kedudukan pengrajin karena ketergantungan pada pemberi pinjaman yang menyebabkan pengrajin tidak mempunyai kekuatan menawarkan di pasar.

Dalam usaha peningkatan pendapatan petani kelapa dan petani pengolah gula kelapa di Desa Pelanduk, sangat erat kaitannya dengan pola atau sistem pemasaran yang berlaku di Desa Pelanduk. Kenyataannya didalam sistem pemasaran menunjukkan bahwa petani selalu berada pada posisi yang lemah dalam penetapan harga apabila berhadapan dengan pedagang. Berdasarkan permasalahan tersebut maka dilakukan analisis pemasaran kelapa dan produk turunannya yaitu gula kelapa yang ada di Desa Pelanduk Kecamatan Mandah.

\section{METODOLOGI} PENELITIAN

\subsection{Waktu dan Tempat Penelitian}

Metode penelitian ini menggunakan metode survey lapangan yang dilaksanakan di Desa Pelanduk Kecamatan Mandah Kabupaten Indragiri Hilir. Pemilihan lokasi secara sengaja berdasarkan pertimbangan bahwa Desa Pelanduk adalah daerah penghasil kelapa dan gula kelapa di Kecamatan Mandah yang terus mengalami peningkatan dari tahun ke tahun. Penelitian dilakukan selama 4 bulan.

\subsection{Teknik Pengambilan Sampel}

Jumlah sampel yang diambil untuk petani kelapa adalah sebanyak 30 orang petani kelapa di Desa Pelanduk, dan 3 orang pedagang pengumpul.Metode penentuan sampel untuk petani gula kelapa di Desa Pelanduk dilakukan dengan metode Purposive Sampling dengan memilih 15 petani secara sengaja sebagai sampel dari 30 petani sebagai populasi. Besar sampel tersebut dianggap mewakili populasi.

Pengambilan sampel pedagang menggunakan metode snowball sampling. Metode tersebut digunakan untuk mengambil sampel pedagang berdasarkan aliran produk, mulai dari petani sampel sampai pedagang pengencer. Jumlah sampel pedagang sebanyak 14 orang, terdiri dari 4 orang pedagang pengumpul dan 10 orang pedagang pengecer.

\subsection{Metode Analisis Data}




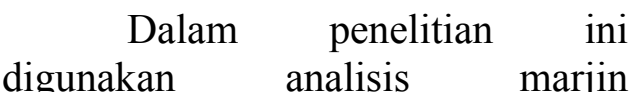
pemasaran, farmer's share pemasaran dan efesiensi pemasaran. Struktur data atau informasi sehubungan dengan pemasaran tersebut disajikan pada tabel 1.

\section{II.3.1. Analisis Marjin Pemasaran}

Menurut Azzaino, marjin pemasaran adalah bagian selisih dari harga yang dibayarkan konsumen akhir dengan harga yang diterima oleh produsen. Marjin pemasaran dapat dirumuskan sebagai berikut :

$$
\mathrm{MP}=\mathrm{Pr}-\mathrm{Pf}
$$

Keterangan :

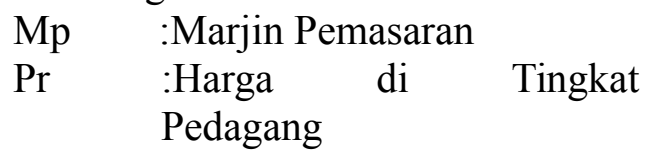

Pf $\quad$ :Harga di Tingkat Petani

II.3.2.

s Farmer's Share

Menurut Darwis (1985), farmer's share adalah bagian harga untuk petani terhadap harga ditingkat pedagang pengumpul. Bagian harga bagi petani dari harga jual kelapa dapat diketahui dengan menggunakan rumus:

$$
S i=\frac{B i}{P r} \times 100
$$

Keterangan :

$\mathrm{Si}$ :Bagian Harga Bagi Petani

Bi :Harga di Tingkat Pedagang Pengumpul

Pr :Harga di Tingkat Petani

\begin{tabular}{|c|c|c|c|c|}
\hline No & Uraian & Satuan & Uraian & Satuan \\
\hline & Petani Kelapa & & Pedagang Pengumpul & \\
\hline 1 & Produksi Panen & $\mathrm{Rp} / \mathrm{Kg}$ & Harga Beli & $\mathrm{Rp} / \mathrm{Kg}$ \\
\hline 2 & Harga Jual & $\mathrm{Rp} / \mathrm{Kg}$ & Harga Jual & $\mathrm{Rp} / \mathrm{Kg}$ \\
\hline 3 & Biaya Transportasi & $\mathrm{Rp} / \mathrm{Kg}$ & Biaya Transportasi & $\mathrm{Rp} / \mathrm{Kg}$ \\
\hline 4 & Biaya Distribusi & $\mathrm{Rp} / \mathrm{Kg}$ & Biaya Distribusi & $\mathrm{Rp} / \mathrm{Kg}$ \\
\hline 5 & Biaya Retribusi & $\mathrm{Rp} / \mathrm{Kg}$ & Biaya Retribusi & $\mathrm{Rp} / \mathrm{Kg}$ \\
\hline 6 & $\begin{array}{l}\text { Jumlah } \\
\text { Pemasaran }\end{array}$ & $\mathrm{Rp} / \mathrm{Kg}$ & $\begin{array}{l}\text { Jumlah } \\
\text { Pemasaran }\end{array}$ & $\mathrm{Rp} / \mathrm{Kg}$ \\
\hline 7 & Farmer's Share & & Farmer's Share & \\
\hline 8 & Marjin Pemasaran & & Marjin Pemasaran & \\
\hline 9 & Efesiensi Pemasaran & & Efesiensi Pemasaran & \\
\hline
\end{tabular}

Tabel 1. Rancangan Komposisi Biaya Pemasaran

II.3.3.

Analisi

\section{s Efesiensi Pemasaran}

Menurut Purcell (1979), efesiensi pemasaran adalah hasil bagi total biaya pemasaran dengan total nilai produk. Efesiensi pemasaran dapat dihitung dengan menggunakan rumus :

$$
E p=x \frac{T B}{T N P} \times 100
$$

Keterangan :

EP : Efesiensi Pemasaran

TB : Total Biaya

TNP : Total Nilai Produksi

III. HASIL DAN PEMBAHASAN

3.1. Saluran Pemasaran Kelapa

Saluran kelapa di Desa Pelanduk melibatkan beberapa lembaga pemasaran yang menyalurkan hasil produksinya. Sedangkan dari hasil penelitian bahwa saluran pemasaran kelapa bulat di Desa Pelanduk terdapat 2 saluran pemasaran. 


\subsubsection{Saluran Pemasaran I}

Berdasarkan dari hasil penelitian tersebut bahwa pedagang pengumpul di Desa Pelanduk terdapat 3 orang pedagang pengumpul. Saluran pemasaran kelapa di Desa Pelanduk dilihat pada gambar 1.

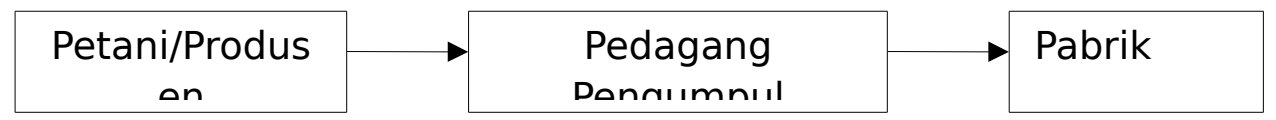

Gambar 1. Skema Saluran Pemasaran I Pemasaran Kelapa

Dari gambar skema tersebut bahwa tidak semua sampel petani di Desa Pelanduk menjual kelapa ke pedagang pengepul, tetapi mereka menjual hasil produksinya langsung ke PT sungai sejuk. Petani yang menjual hasil produksinya itu sendiri ke pedagang pengepul adalah petani yang memiliki jumlah hasil produksinya yang sedikit.

Pada saluran pemasaran I petani langsung menjual hasil produksinya ke pedagang pengepul, selanjutnya pedagang pengepul menjual nya k PT Sungai Sejuk. Volume dengan harga rata-rata kelapa jambul didaerah penelitian pada saluran I yaitu sebesar Rp.9.033,33 per kilogram. Harga yang dibayarkan oleh pedagang pengepul adalah Rp.10.773,33 per kilogram.

\subsubsection{Saluran Pemasaran II}

Pada saluran II pemasaran kelapa di Desa Pelanduk Kecamatan Mandah dapat dilihat pada gambar 2.

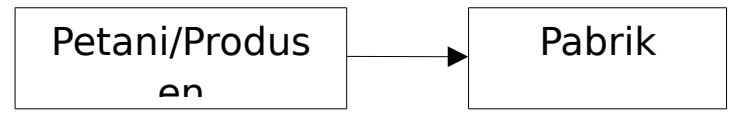

Gambar 2. Saluran Pemasaran II Pemasaran Kelapa

Dari gambar skema tersebut bahwa tidak semua petani di Desa Pelanduk terlibat melakukan pemasaran kelapa pada saluran pemasaran II. Petani yang menjual hasil produksinya ke pabrik PT Sungai Sejuk adalah petani yang memiliki jumlah hasil produksinya yang banyak. Volume dengan harga rata-rata produksi kelapa jambul daerah penelitian yaitu Rp.9.033,33 per kilogram, sedangkan pada saluran II yaitu Rp.10.773,33 per kilogram. Menurut
Arifuddin

(1997), mengatakan panjang pendeknya saluran pemasaran akan menentukan tingkat efesiensi pemasaran, komponen biaya akan semakin bertambah seiring dengan bertambahnya lembaga pemasaran.

Berdasarkan pada uraian saluran pemasaran I dan II dapat disimpulkan bahwa saluran pemasaran I merupakan merupakan saluran terpanjang karena petani langsung menjual hasil produksinya k pabrik PT Sungai Sejuk, sehingga mengidentifikasi tingkat efesiensi 
pemasaran lebih tinggi karena biaya yang dikeluarkan relatif kecil. Pada saluran pemasaran II merupakan saluran pemasaran yang terpendek, sehingga mengidentifikasi tingkat efesiensi pemasaran lebih rendah karena biaya yang dikeluarkan relatif besar.

\subsection{Saluran Pemasaran Gula Kelapa \\ Saluran pemasaran gula} kelapa di Desa Pelanduk terdapat 3 jenis saluran pemasaran.

\subsubsection{Saluran I}

\section{Petani $\rightarrow$ Konsumen}

Gambar 3. Skema Saluran I Pemasaran Gula Kelapa

\subsubsection{Saluran II}

Pada saluran II ini petani menjual gula kelapa kepada pedagang pengumpul dan pedagang pengumpul ini langsung mengecer gula kelapa ke konsumen dengan harga beli rata-rata sebesar
Pada saluran I petani memasarkan gula kelapanya sendiri karena gula kelapa yang dihasilkan dalam jumlah sedikit. Petani menjual gula kelapa tersebut dengan harga jual rata-rata pada konsumen akhir sebesar Rp 11.066,67 per kg. Gula kelapa pada saluran I ini dipasarkan langsung oleh petani sampel dengan alasan bahwa harga jual pada konsumen akhir lebih tinggi jika dibandingkan dengan para pedagang pengumpul atau pedagang pengecer sehingga pendapatan petani lebih tinggi. Skema saluran I dapat dilhat pada gambar 3 .

Rp 8.500,00 per kg, sedangkan harga rata-rata yang harus dibayar oleh konsumen akhir adalah sebesar Rp 13.250,00 per kg. Skema saluran II dapat dilihat pada Gambar 4.

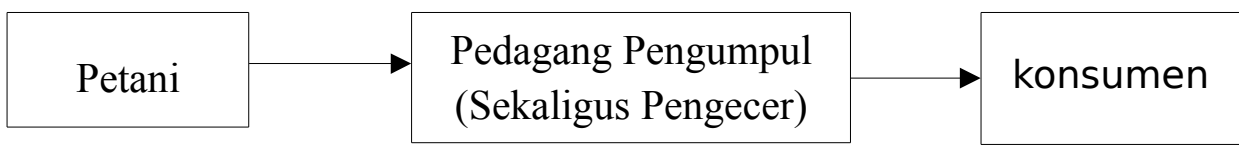

Gambar 4. Skema Saluran II Pemasaran Gula Kelapa

Pedagang pengumpul tersebut membeli gula kelapa dari petani sebagai produsen. Pedagang pengumpul membeli gula kelapa dari petani dengan satuan kilo gram dan membayarnya sebagian dari jumlah yang diterima oleh petani dan akan melunasinya setelah gula kelapa laku terjual. Baru kemudian pedagang pengumpul melunasi sisa pembayaran kepada petani.

\subsubsection{Saluran III}

Pada saluran III ini petani menjual gula kelapa kepada pedagang pengumpul dengan ratarata penjualan sebanyak $106,25 \mathrm{~kg}$ dengan harga $\mathrm{Rp} 8.500,00$ per $\mathrm{kg}$. Pedagang pengumpul tersebut membawa gula kelapa yang telah dibeli dari petani ke Kota Tembilahan dan menjualnya kembali kepada pedagang pengecer dengan harga rata-rata $\mathrm{Rp} 10.875$ per $\mathrm{kg}$. 
Skema saluran pemasaran III dijelaskan pada gambar 5 .

\begin{tabular}{|c|c|c|c|c|}
\hline Pedani \\
Pengumpul
\end{tabular}$\rightarrow \begin{gathered}\text { Pedagang } \\
\text { Pengecer }\end{gathered} \rightarrow$ Konsumen

Gambar 5. Skema Saluran III Pemasaran Gula Kelapa

Pedagang pengumpul tersebut membeli gula kelapa dari petani sebagai produsen gula kelapa. Pedagang pengumpul membeli gula kelapa dari petani dengan satuan kilogram dan membayarnya sebagian dari jumlah yang diterima oleh petani dan akan melunasinya setelah gula kelapa diantar ke pedagang pengecer dan dibayar oleh pedagang pengecer dengan tunai.

Kemudian pedagang pengecer menjual gula kelapa yang telah dibeli dari pedagang pengumpul yang berasal dari Desa Pelanduk tersebut kepada konsumen akhir yang ada di Kota Tembilahan dengan harga rata-rata $\mathrm{Rp} 13.700,00$ per $\mathrm{kg}$.

\subsection{Analisis Pemasaran Kelapa}

Analisis pemasaran kelapa di Desa Pelanduk mengguanakan analisis margin pemasaran,analisis farmer's share dan efesiensi pemasaran.

\subsubsection{Analisis Margin Pemasaran}

Menurut Hanafiah (1986), menjelaskan bahwa margin pemasaran terdiri dari biaya yang dikeluarkan dan keuntungan lembaga pemasaran. Semakin tinggi biaya yang dikeluarkan maka semakin besar margin pemasranya. Total margin sangat berpengaruh harga ditingkat petani dan bagian harga untuk kunsumen.

Margin pemasaran dapat diketahui dengan hasil dari selisih harga ditingkat petani dengan selisih harga ditingkat pedagang. keuntungan lembaga pemasaran merupakan salah satu komponen margin pemasaran. Jumlah keuntungan akan menentukan besarnya bagian harga untuk konsumen atau pabrik. Dalam ananlisis ini pemasaran melibat dua komponen, yaitu harga jual dan harga beli. Data mengenai margin pemasaran kelapa disajikan pada tabel 2.

Tabel 2. Margin Pemasaran Kelapa di Desa Pelanduk

\begin{tabular}{llll}
\hline Besarnya Margin & & \\
\hline Saluran I & & Saluran II & \\
\hline $\mathrm{Rp} / \mathrm{kg}$ & $\%$ & $\mathrm{Rp} / \mathrm{kg}$ & $\%$ \\
$1.740,000$ & $58 \%$ & 1,140 & 38 \\
\hline
\end{tabular}

Sumber: Data Skunder diolah.2013

Tabel 2 menunjukan bahwa pada saluran I memiliki margin yang terbesar adalah Rp. 1,740 per kilogram dari total pemasaran atau $58,00 \%$, sedangkan pada saluran II memiliki margin yang terkecil adalah 
Rp.1,140 per kilogram atau $38,00 \%$ dari harga jual rata-rata tingkat konsumen yang dalam hali ini konsumen akhir kelapa ini adalah pabrik PT Sungai Sejuk.

\subsubsection{Analisis Farmer's share}

Menurut Azzaino (1981), menjelaskan bahwa semakin tinggi margin pemasaran maka semakin rendah bagian harga untuk petani (farmer's share). Farmer's share dapat diketahui dengan membandingkan harga tingkat pedagang.

Menurut Azzaino (1981),mengatakan bahwa semakin panjang saluran pemasaran mengakibatkan biaya semakin banyak. Hal tersebut sesuai dengan kondisi pemasaran kelapa di Desa Pelanduk yaitu saluran II memiliki biaya pemasaran paling tinggi dan waktu yang sangat lama.

Margin pemasaran dapat digunakan untuk mengetahui distribusi margin pemasaran serta untuk mengetahui bagian harga untukmpetani (farmer's share). Besarnya margin pemasaran mempengaruhi besarnya bagian bagian dan keuntungan lembaga pemasaran. Farmer's share dan keuntungan pedagang pada pemasaran kelapa di Desa Pelanduk dapat dilihat pada tabel 3 .

Tabel 3. Farmer's share Biaya Pemasaran Kelapa di Desa Pelanduk

\begin{tabular}{llllll}
\hline \multirow{2}{*}{ No } & \multirow{2}{*}{ Uraian } & \multicolumn{3}{l}{ Pola Pemasaran } \\
\cline { 3 - 6 } & & \multicolumn{2}{l}{ Saluran I } & \multicolumn{2}{l}{ Saluran II } \\
\cline { 2 - 5 } & $\mathrm{Rp} / \mathrm{Kg}$ & $\%$ & $\mathrm{Rp} / \mathrm{Kg}$ & $\%$ \\
\hline 1 & Farmer's share & 10,77 & 3,59 & 70,21 & 234,03 \\
2 & Biaya Pemasaran & & & & \\
& Transfortasi & 33,50 & 111,66 & 5,40 & 1,08 \\
& Distribusi & - & & 4,90 & 9,80 \\
& Retribusi & 18,20 & 606,66 & 6,40 & 1,28 \\
\hline & Sub Total & 51,70 & 11,772 & $5.126,60$ & 24,619 \\
\hline
\end{tabular}

Sumber: Data Primer diolah,2013

Tabel 3 menunjukan bahwa pada lembaga saluran pemasaran I memiliki farmer's share biaya pemasaran terkecil yaitu Rp.10,77 per kilogram total pemasaran atau $3,59 \%$. sedangkan pada saluran pemasaran II memiliki farmer's share biaya pemasaran yang terbersar yaitu Rp.70,21 per kilogram dari total pemasaran ayau $234,03 \%$.

Berdasarkan dari hasil penelitian pemasaran kelapa di Desa Pelanduk bahwa saluran pemasaran paling efesiensi berdasarkan besarnya farme's share adalah saluran II karena disini petani kelapa itu sendiri yang melakukan kegiatan pemasaran.

\subsubsection{Analisis Efesiensi Pemasaran}

Menurut purcell (1979), mengatakan bahwa setiap perubahan biaya pemasaran dan semakin kecil nilai produksi yang dijual dan memberikan arti bahwa hal ini menyebabkan adanya pemasaran yang kurang efesiensi. Jadi apabila semakin kecil nilai Ep maka semakin efesiensi pemasaran tersebut. Efesiensi pemasaran pada saluran pemasaran kelapa di Desa Pelanduk tersaji pada tabel 4 . 
Tabel 4. Efesiensi pemasaran pada Saluran Pemasaran Kelapa di Desa Pelanduk

\begin{tabular}{lllll}
\hline \multirow{2}{*}{ No. Saluran Pemasaran } & $\begin{array}{l}\text { Biaya Pemasaran } \\
\mathrm{Rp} / \mathrm{Kg}\end{array}$ & $\begin{array}{l}\text { Nilai Produk } \\
\mathrm{Rp}\end{array}$ & \multirow{2}{*}{ Ep (\%) } \\
\hline 1 & I & $3,532,00$ & $10.773,33$ & 3,90 \\
2 & II & 13,89 & 76,560 & 8,26 \\
\hline Jumlah Total & $5.178,30$ & $1.153,893$ & 12,16 \\
\hline
\end{tabular}

Sumber: Data Primer diolah,2013

Tabel 4 menunjukan bahwa pada lembaga saluran pemasaran I memiliki tingkat efesiensi pemasaran yang terkecil yaitu 3,90\% dari total pemasaran, sedangkan pada saluran pemasaran II memiliki tingkat efesiensi pemasaran yang terbesar yaitu 8,26 dari total pemasaran. Menurut Mubyarto (1989), Menjelaskan bahwa setiap penambahan biaya pemasaran dan semkin kecil nilai produksi yang dijual memberikan makna bahwa hal ini menyebabkan adanya pemasaran yang tidak efesiensi. Jadi apabila semakin nilai Ef maka akan semakin efesiensi pemsaranya.

Pada saluran II Besarnya Marjin persentase biaya yang dikeluarkan relative kecil apabila dibandingkan dengan saluran pemasaran I, disebabkan karena pada saluran I dalam pemasaran kelapa di Desa Pelanduk melibatkan pedagang pengumpul, yang berperan dalam memasarkan hasil produksi kelapa tersebut adalah petani kelap itu sendiri, sehingga harga jual kelapa yang diterima oleh petani lebih tinggi.

\subsection{Analisis Pemasaran Gula Kelapa}

3.4.1.Analisis Marjin Pemasaran

Marjin adalah selisih harga yang harus di bayar oleh konsumen akhir dengan harga yang diterima oleh petani. Pembahasan dalam analisis marjin pemasaran mencakup dua komponen yaitu harga jual dan harga beli pada lembaga pemasaran. Data mengenai marjin pemasaran tersaji pada Tabel 5.

Tabel 5 menunjukan bahwa lembaga pemasaran pada saluran II adalah pedagang pengumpul yang sekaligus pengecer. Besarnya marjin pemasaran disaluran II sebesar Rp4.750,00 per kilogram atau 35,85 $\%$ dari harga jual rata-rata ditingkat konsumen. Harga jual gula kelapa di tingkat konsumen akhir adalah sebesar Rp 13.250,00Per kilogram.

Tabel 5. Marjin Pemasaran Gula Kelapa di Desa Pelanduk Kecamatan Mandah

\begin{tabular}{llllll}
\hline \multirow{2}{*}{ No } & Jenis Lembaga & \multicolumn{3}{l}{ Lembaga Pemasaran } \\
\cline { 3 - 6 } & & \multicolumn{2}{l}{ Saluran II } & Saluran III \\
\cline { 3 - 6 } & & $\mathrm{Rp} / \mathrm{kg}$ & $\%$ & $\mathrm{Rp} / \mathrm{kg}$ & $\%$ \\
\hline 1 & Pedagang pengumpul & $4.750,00$ & 100,00 & $2.375,00$ & 43,78 \\
2 & Pedagang pengecer & - & - & $3.050,00$ & 56,22 \\
& & $4.750,00$ & 100,00 & $5.425,00$ & 100,00 \\
\hline
\end{tabular}

Sumber: Data primer yang diolah, 2013 
Lembaga pemasaran pada saluran III adalah pedagang pengumpul dan pedagang pengecer. Besarnya marjin pemasaran pada saluran III adalah Rp 5.425,00 per kilogram atau 39,60\% dari harga jual rata-rata di tingkat konsumen. Harga jual rata-rata gula kelapa di tingkat konsumen akhir pada saluran pemasaran III adalah Rp13.700 per kilogram. Pada saluran III ada keterlibatan dua lembaga pemasaran yaitu pedagang pengumpul dan pedagang pengecer yang menyebabkan marjin pada saluran III lebih besar pada Saluran II yaitu sebesar Rp 5.425,00 per kilogram. Menurut Soekartawi (1995), bahwa semakin panjang saluran pemasaran maka akan semakin besar marjin pemasaran tersebut. Hal ini menunjukkan bahwa pemasaran kurang efisien.

Pada saluran I petani tidak menjual gula kelapa kepada pedagang baik pedagang pengumpul atau pedagang pengecer. Hal ini dikarenakan harga yang didapatkan lebih tinggi jika menjual sendiri gula kelapa tersebut kepada konsumen. Pada saluran I yang menjadi pemasarannya yaitu petani sendiri disini bisa dikatakan bahwa petani tersebut sekaligus sebagai pedagang.

Menurut Sudiyono (2001), semakin kecil nilai marjin pemasaran akan mengidentifikasi tingkat efisien saluran pemasaran semakin tinggi dan sebaliknya apabila nilai marjin pemasaran semakin besar maka akan mengidentifikasikan tingkat efisiensi saluran pemasaran semakin rendah.

\subsubsection{Analisis Pemasaran}

Efisiensi pemasaran adalah seberapa besar pengorbanan yang harus dikeluarkan dalam kegiatan pemasaran menunjang hasil yang bisa didapatkan dari kegiatan pemasaran tersebut. Efisiensi pemasaran dapat dicari dengan menghitung rasio "keluaranmasukan" dalam kegiatan pemasaran yang dilakukan. Semakin tinggi nilai rasio keluaran-masukan, maka pemasaran yang dilakukan semakin efisien. Dalam rangka perbaikan pemasaran tujuan yang ingin dicapai adalah keuntungan yang maksimum dan sangat efisiensi yang tinggi.

Efisiensi pemasaran merupakan salah satu indikator baik atau tidaknya di dalam pemasaran. Kegiatan ekonomi produktif selalu berkaitan dengan efisiensi ekonomi. Dalam rangka perbaikan pemasaran tujuan yang ingin dicapai adalah keuntungan yang maksimum dan sangat efisiensi yang tinggi.

Sistem pemasaran yang tidak efisien akan mengakibatkan kecilnya bagian dari harga yang diterima oleh produsen, jadi bagian harga yang dibayar oleh konsumen yang diterima oleh produsen dapat dijadikan ukuran efisiensi pemasaran. Setiap penambahan biaya pemasaran dan semakin kecil nilai produk yang dijual memberikan arti bahwa pemasaran kurang efisien. Untuk lebih jelasnya mengenai efisiensi dapat dilihat pada Tabel 6 .

Tabel 6 menunjukan bahwa pada lembaga saluran pemasaran I memiliki tingkat efisiensi yaitu sebesar $0,67 \%$ dari total nilai penjualan. Sedangkan pada lembaga saluran pemasaran II memiliki tingkat efisiensi sebesar $1,21 \%$ dari total nilai penjualan. Dan pada lembaga saluran pemasaran III memiliki tingkat efisiensi sebesar $6,15 \%$ dari total nilai penjualan. Untuk lebih jelasnya mengenai 
perhitungan efisiensi pemasaran dapat dilihat pada lampiran 5 .

Pada saluran I biaya pemasaran paling kecil yaitu sebesar Rp 74,33, jika dibandingkan dengan saluran II yaitu sebesar Rp 159,73. Dan pada saluran III yaitu sebesar Rp 760,40. Pada saluran II pemasaran dilakukan oleh pedagang pengecer dan biaya yang dikeluarkan lebih besar dari saluran I. pada saluran III pemasaran dilakukan oleh dua lembaga pemasaran yaitu pedagang pengumpul dan pedagang pengecer sehingga biaya pemasaran lebih besar dari saluran I dan saluran II.

Pada saluran I petani menjual gula kelapanya sendiri kepada konsumen karena harga yang didapat lebih tinggi dari pada harus menjual kepada pedagang pengumpul atau pedagang pengencer. Sebaiknya para petani melakukan pemasaran sendiri dari hasil gula kelapa yang ada karena hasil yang didapat akan lebih besar dan dari segi atau tingkat efisien saluran I merupakan jenis saluran yang paling efisien jika dibandingkan dengan saluran II dan saluran III. Saluran III merupakan jenis saluran yang tidak efisien karena dari segi biaya yang dikeluarkan lebih besar dari saluran I dan II karena pada saluran III pemasaran dilakukan oleh pedagang pengumpul dan pedagang pengecer.

Tabel 6. Efisiensi Pemasaran Gula Kelapa di Desa Pelanduk Kecamatan Mandah.

\begin{tabular}{|c|c|c|c|c|}
\hline \multirow[b]{2}{*}{ No } & \multicolumn{4}{|c|}{ Pola Pemasaran } \\
\hline & Uraian & $\begin{array}{c}\text { Saluran I } \\
\mathrm{Rp} / \mathrm{kg}\end{array}$ & $\begin{array}{c}\text { Saluran II } \\
\mathrm{Rp} / \mathrm{kg}\end{array}$ & $\begin{array}{c}\text { Saluran III } \\
\mathrm{Rp} / \mathrm{kg}\end{array}$ \\
\hline $\mathrm{A}$ & Petani & & & \\
\hline 1 & Harga Jual & $11.066,67$ & & \\
\hline 2 & Biaya Trasportasi & & & \\
\hline 3 & Biaya Penyusutan & & & \\
\hline 4 & Biaya Pengemasan & 74,33 & & \\
\hline 5 & Biaya Restribusi & & & \\
\hline 6 & Total Biaya & 74,33 & & \\
\hline 7 & Efisiensi (\%) & 0,67 & & \\
\hline $\mathrm{B}$ & Pedagang Pengumpul & & & \\
\hline 1 & Harga Beli & & $8.500,00$ & $8.500,00$ \\
\hline 2 & Harga Jual & & $13.250,00$ & $10.875,00$ \\
\hline 3 & Biaya Trasportasi & & 56,72 & 52,44 \\
\hline 4 & Biaya Penyusutan & & 2,50 & 179,22 \\
\hline 5 & Biaya Pengemasan & & 43,79 & 38,14 \\
\hline 6 & Biaya Restribusi & & 56,72 & 47,68 \\
\hline 7 & Total Biaya & & 159,73 & 317,48 \\
\hline 8 & Efisiensi (\%) & & 1,21 & 2,92 \\
\hline $\mathrm{C}$ & Pedagang Pengecer & & & \\
\hline 1 & Harga Beli & & & $10.650,00$ \\
\hline 2 & Harga Jual & & & $13.700,00$ \\
\hline 3 & Biaya Trasportasi & & & 65,33 \\
\hline 4 & Biaya Penyusutan & & & 177,49 \\
\hline 5 & Biaya Pengemasan & & & 133,40 \\
\hline
\end{tabular}


D Total Biaya

Total Efisiensi

74,33

Sumber: Data primer yang diolah, 2013

Hasil penelitian pemasaran gula kelapa di Desa Pelanduk Kecamatan Mandah menunjukan bahwa lembaga saluran pemasaran I adalah lembaga saluran pemasaran yang paling efisien. Hal ini dikarenakan biaya yang dikeluarkan lebih rendah jika dibandingkan dengan lembaga saluran pemasaran II dan lembaga saluran III.

Setiap penambahan biaya pemasaran dan semakin kecil nilai produk yang dijual memberikan arti bahwa hal ini menyebabkan adanya pemasaran yang kurang efisien. Jadi apabila semakin kecil nilai Ep maka akan semakin efisien pemasaran tersebut (murbyanto, 1997).

Lembaga saluran pemasaran I adalah lembaga saluran pemasaran terpendek yang tidak melibatkan pedagang di dalam memasarkan gula kelapanya. Hal ini dikarenakan petani mejualnya sendiri kepada konsumen, sehingga mengidentifikasikan tingkat efisien pemasaran lebih tinggi.

Menurut Open dan Raju dalam Arifuddin (1997), panjang pendeknya saluran pemasaran akan menenukan tingkat efisiensi pemasaran. Komponen biaya akan semakin bertambah dengan seiring dengan bertambahnya lembaga pemasaran.

Sesuai dengan hasil penelitian Lantika.S.Y. (2007), menunjukan bahwa saluran I mempunyai tingkat efisien yang tinggi jika dibandingkan dengan saluran II dan III dan biaya yang paling sedikit terdapat pada saluran I yaitu sebesar Rp230,00 sementara saluran II sebesar Rp 250,00 dan Saluran III sebesar Rp 870,00, jadi dari hasil penelitian dapat dikatakan bahwa saluran I adalah saluran yang paling efisien jika dibanding dengan saluran II dan III.

IV. KESIMPULAN DAN SARAN

\subsection{Kesimpulan}

1. Margin pemasaran kelapa pada saluran 1 adalah Rp.1.740,00 atau $58,00 \%$, sedangkan margin pada saluran II adalah Rp.1,140 atau $38,00 \%$.

2. Farmer's share kelapa pada saluran I yaitu Rp.10,77 atau 3,59\% sedangkan pada farmer's share pada saluran II yaitu Rp.70,21 atau 234,03\%

3. Efesiensi pemasaran kelapa pada saluran I yaitu 3,90\%, sedangkan efesiensi pada saluran II yaitu $8,26 \%$.

4. Besarnya marjin pemasaran gula kelapa pada saluran II adalah Rp 4.750,00 dan pada saluran III sebesar Rp 5.425,00 per kilogram. Pada saluran I tidak terdapat marjin pemasaran karena petani menjual sendiri gula kelapanya kepada konsumen.

5. Nilai efisiensi gula kelapa pada saluran I adalah $0,67 \%$, dan saluran II sebesar 1,21\% sedangkan pada saluran III yaitu sebesar $6,15 \%$. Sehingga saluran 
I merupakan saluran pemasaran yang paling efisien didaerah penelitian karena memiliki nilai efisiensi paling kecil.

\subsection{Saran}

1. Perlunya pengembangan media informasi harga sampai tingkat petani, misalnya melalui penyuluhan pertanian. Informasi harga diharapkan dapat membantu petani dalam merencanakan dan menentukan harga kelapa serta melancarkan dalam proses pemasaran.

2. Petani kelapa disarankan menjual langsung hasil produksinya ke pabrik atau PT, tanpa melaluin perantara sehingga harga jual kelapa menjadi lebih tinggi dan keuntungan petani lebih tinggi jika produksinya banyak.

3. Bagi petani gula kelapa, hasil penelitian ini menunjukkan bahwa analisis gula kelapa layak dan menguntungkan, sehingga petani diharapkan sangat perlu meningkatkan penggunaan input yang baik sehingga dapat meningkatkan produksi dan pendapatan yang diperoleh sesuai dengan yang diharapkan. Salah satunya dengan pengadaan pembudidayaan gula kelapa secara intensif untuk menggantikan pohon kelapa yang sudah tidak produktiv lagi. Pada pola pemasaran, petani sebaiknya mengikuti pelatihan mengenai pemasaran yang baik untuk meningkatkan penjualan produknya dan mendapatkan harga yang baik.

4. Bagi pemerintah daerah, agar mendorong pengembangan agroindustri gula kelapa dengan diintensifkannya penyuluhan tentang penerapan pengolahan agroindustri yang baik agar usaha gula kelapa ini tetap layak diusahakan dan mampu memasuki pasar ekspor. Selain itu diharapkan pemberian bantuan pinjaman modal kepada petani gula kelapa dengan syarat yang mudah, sehingga dapat mendukung peningkatan produksi dan kualitas produksi gula kelapa yang dihasilkan.

\section{DAFTAR PUSTAKA}

Azzaino, 1990. Pengantar Tataniaga Pertanian. Departemen Ilmu Ilmu Sosial Ekonomi Pertanian. Fakultas Pertanian IPB. Bogor.

Arifuddin,1997. Dasar-dasar Agribisnis. Jurusan Sosial Ekonomi. Fakultas Pertanian. Universitas Brawijaya. Malang.

Azzaino,z. 1981. Pengantar Tataniaga Pertanian. Departemen Ilmu-ilmu Sosial ekonomi Pertanian. Fakultas Pertanian IPB. Bogor.

Hanafiah,S. 1986 Tataniaga Hasil Perikanan. UI press. Jakarta.

Luntungan et al, 2005. Pengantar Ekonomi Sumberdaya Manusia, Fakultas Ekonomi, Universitas Indonesia. Jakarta

Mubyarto, 1989. Pengantar Ilmu Ekonomi. LP3S. Jakarta.

Mubyarto, 1997. Pengantar Ekonomi Pertanian. Lembaga Penelitian 
Pendidikan dan Ilmu ekonomi, dan Sosial. Yogyakarta.

Puecell, 1979. Agricultural Marketing. Reston Publishing Company,inc. Pretince Hall Company. Reston, Virginia.
Sudiyono, A, 2001.Pemasaran Pertanian. Universitas Muhamadiyah. Malang.

Soekartawi, A, 2001. Prinsip Dasar Ekonomi Pertanian Tiore dan Aplikasi, Rajawali Press. Jakarta. 
